Gut, 1987, 28, S1, 243-247

\title{
Characterisation of humoral trophic factors involved in intestinal adaptation using a 3T3 cell growth factor assay
}

\author{
J A BILLER, R K MONTGOMERY, R J GRAND, M KLAGSBRUN, \\ AND A ROSENTHAL
}

From the Division of Pediatric Gastroenterology and Nutrition, Boston Floating Hospital, New England Medical Center; Department of Pediatrics, Tufts University School of Medicine, and Department of Surcery, Children's Hospital and Harvard Medical School, Boston, MA, USA

SUMMARY Indirect evidence has suggested that circulating trophic factor(s) are involved in intestinal adaptation. A 3T3 fibroblast cell culture system was used to more directly delineate the presence of such factors. Rats were divided into four groups; C-unop, those undergoing no surgery, $\mathrm{S}$, those in which a dorsal slit was made; $\mathrm{C}$-op, those in which the peritoneum was incised; and $\mathbf{R}$, those undergoing $80 \%$ intestinal resection. At the time of death at 24 hours, one week and two weeks postoperative, stimulation of DNA synthesis in the 3T3 cells was noted after incubation with platelet free plasma from the C-op and R groups, and simultaneously an increase in ileal DNA specific activity occurred. Characterisation of the plasma fraction with growth factor activity revealed it to have a MW of greater than 6000 and less than $14000 \mathrm{~d}$. The factor(s) was resistent to reduction with DTT, and was partially inactivated by heating to $60^{\circ} \mathrm{C}$. The use of $3 \mathrm{~T} 3$ cell growth factor assay system allows further characterisation of circulating factors involved in intestinal adaptation.

The small intestine undergoes a series of complex histological and functional changes after limited surgical resection, enabling the organism to adapt to the reduced absorptive surface..$^{1-6}$ Enteral nutrition plays a major trophic role in intestinal adaptation which occurs distal to the site of the resection. ${ }^{7-9}$ Luminal factors cannot, however, explain all of the changes occurring in the adaptation process, and experimental evidence indirectly suggests the presence of circulating humoral factors with trophic effects on small intestinal mucosa.

The difficulty in documenting and characterising the presence of humoral growth factors after intestinal resection has, in part, been related to a lack of a reproducible in vitro assay for growth factor activity. The 3T3 cell culture system used in the present study has been shown previously to be a reproducible assay for growth factor activity for epidermal growth factor, ${ }^{10}$ platelet derived growth factor ${ }^{11}$ and fibroblast growth factor. ${ }^{12}$

Address for correspondence: Jeffrey A Biller, MD, Division of Pediatric Gastroenterology and Nutrition, Box 213, New England Medical Center, 171 Harrison Avenue, Boston, Massachusetts 02111, USA.
In this study we present evidence supporting the usefulness of the 3T3 cell growth factor assay for detecting and further characterising such circulating trophic factors.

\section{Methods}

These experiments were conducted using male Sprague-Dawley derived rats (151-175 g). One hundred twenty rats were divided equally among three control groups and one resected group as follows:

(1) The unoperated controls (C-unop), which included those rats anaesthetised, but in which no operation was performed;

(2) The dorsal slit group (S), comprised those rats in which a $3 \mathrm{~cm}$ incision was made on the back of the animal, with the subcutaneous tissue torn using a clamp;

(3) The operated control group (C-op) which included those rats in which a $3 \mathrm{~cm}$ abdominal incision was made and the peritoneum incised, but the bowel was not manipulated; 
(4) The resected group (R) comprised rats that underwent an $80 \%$ proximal small intestinal resection with a primary anastomosis of the remaining segments.

Ten rats in each group were killed at either 24 hours, one week, or two weeks after start of the experiment. One hour before death, rats were injected intraperitoneally with $50 \mu \mathrm{Ci}$ of ${ }^{3} \mathrm{H}$ thymidine. At the time of death, blood was collected for the in vitro 3T3 growth factor assay (see below). In addition, a $5 \mathrm{~cm}$ segment of ileum was removed, and mucosa was obtained and stored at $-40^{\circ} \mathrm{C}$ until used to measure the incorporation of ${ }^{3} \mathrm{H}$ thymidine into DNA (see below).

IN VITRO GROWTH FACTOR ASSAY

Mouse BALB/c 3T3 embryo fibroblasts (clone A 31) were used in the in vitro growth factor assay as previously reported. ${ }^{13}$ The $3 T 3$ cells were incubated for seven to 10 days without a medium change in order to yield confluent monolayers of nondividing cells.

Platelet free plasma was obtained ${ }^{14}$ and after a dose response curve was calculated, aliquots were added to the 3T3 microtiter wells, together with ${ }^{3} \mathrm{H}$ thymidine. After incubation for 48 hours, incorporation of ${ }^{3} \mathrm{H}$ thymidine into DNA (CPM/ $\mu$ g DNA) was determined $^{1315}$ and expressed as units of activity per $\mathrm{ml}$ of platelet free plasma, with one unit of activity equalling the volume necessary to give half maximal stimulation.

IN VIVO DNA SYNTHESIS

Extraction of ileal DNA was carried out as previously reported $^{1617}$ and results expressed as mg of DNA per $5 \mathrm{~cm}$ segment. Aliquots of the pure DNA solution were counted and DNA specific activity (SA) expressed as counts per minute per $\mu \mathrm{g}$ DNA was calculated.

\section{CHARACTERISATION OF PLASMA GROWTH FACTOR}

To establish a range for the molecular weight of the plasma fraction containing in vitro growth factor activity, platelet free plasma was sequentially dialysed against Ringer's solution using membranes with pore sizes $3500 \mathrm{~d}, 6000-8000 \mathrm{~d}$ and then $12000-14000 \mathrm{~d}$. The growth factor activity of the dialysed sample was measured in the 3T3 cell system as described above. In a separate experiment, plasma samples were assayed before and after heating at $60^{\circ} \mathrm{C}$ for 30 minutes and pre- and post-treatment with $5 \mathrm{mmol}$ dithiothreitol (DTT) for one hour.

\section{AUTORADIOGRAPHIC AND HISTOLOGIC STUDIES}

Autoradiographic ${ }^{18}$ and histological studies of ileal

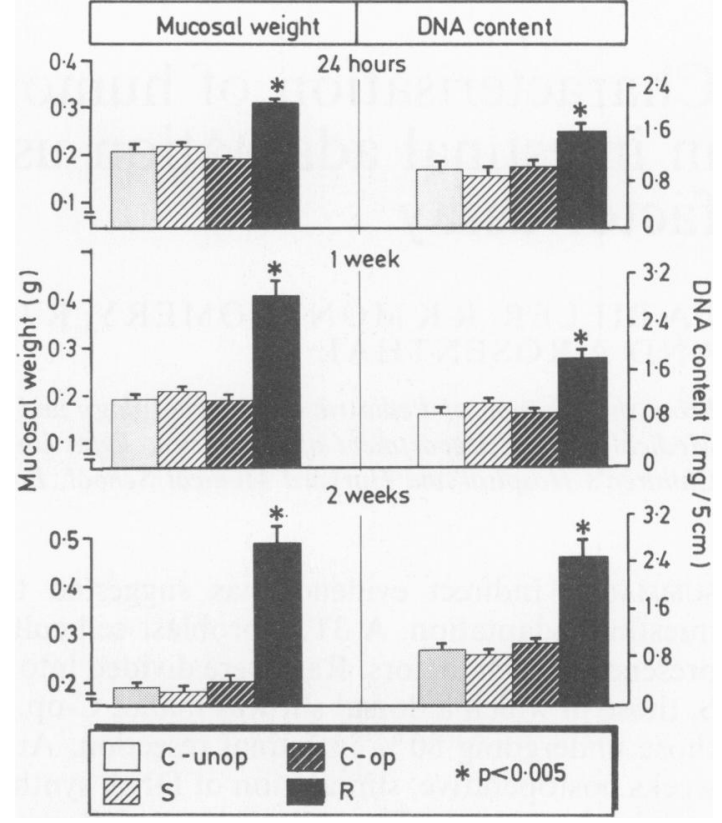

Fig. 1 Mucosal weight (g) and DNA content (mg) per $5 \mathrm{~cm}$ ileal segment (mean $\pm S E$ ), is shown for each group at time of death (24 hours, 1 week, and 2 weeks).

mucosa were prepared from a randomised group of animals killed at two weeks postoperatively. Villous height and crypt depth were calculated as well as the number of labelled crypt cells and labelling index (percentage of the crypt cells labelled).

\section{Results}

\section{MUCOSAL DNA EXTRACTION}

As noted in Figure 1, there was no significant difference for either mucosal weight or DNA per segment $(\mathrm{mg} / 5 \mathrm{~cm})$ at any of the time points among the unoperated animals (C-unop), those undergoing either a dorsal skin incision (S) or those undergoing peritoneal incision (C-op). There was, however, a significant increase in both mucosal weight and DNA content per $5 \mathrm{~cm}$ segment for those undergoing an intestinal resection at each time point compared to controls $(p<0.005)$.

\section{HOURS POSTOPERATIVE}

At 24 hours (Fig. 2), the 3T3 assay revealed significant stimulation by plasma from both the operated control animals (C-op) and those undergoing intestinal resection $(R)$ as compared with the unoperated control $(p<0.025, p<0.005$, respectively). At the same time, there was significant stimulation of DNA 


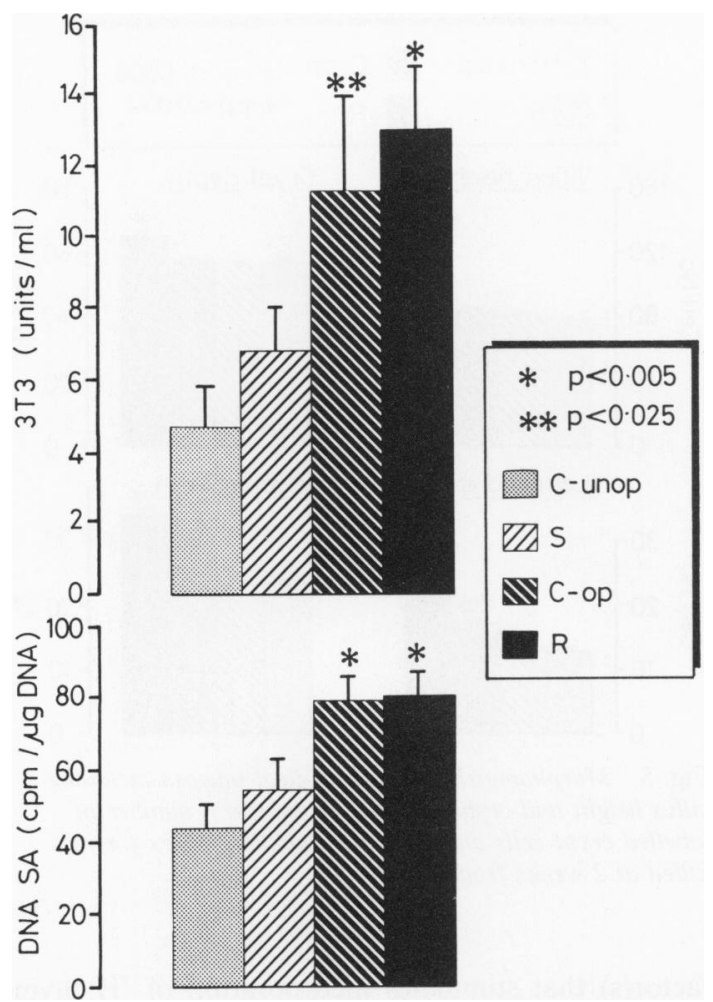

Fig. 2 Degree of $3 T 3$ cell stimulation (units of activity/ml plasma) by platelet free plasma, and DNA $S A$ (cpm/ $\mathrm{gg}$ DNA) for each group at 24 hours postoperative. Shown are the means $\pm S E$ and statistics reflect comparison to $C$-unop group using Student's t test.

SA for those two groups as compared with the unoperated animals ( $p<0.005$ for each).

\section{ONE WEEK POSTOPERATIVE}

At one week after operation (Fig. 3), stimulation of 3T3 cell proliferation by plasma from the resected group was significantly greater than that of the unoperated animals $(p<0.025)$. Stimulation by the plasma from the group undergoing peritoneal incision (C-op) increased but did not reach statistical significance. The DNA SA increased significantly for both those undergoing peritoneal incision alone (C-op), as well as those with intestinal resection $(R)(p<0.01$, $\mathrm{p}<0.005$ respectively).

\section{TWO WEEKS POSTOPERATIVE}

At two weeks after operation (Fig. 4) the plasma of rats undergoing peritoneal incision (C-op) and intestinal resection $(R)$ significantly stimulated $3 T 3$ cell proliferation as compared with the unoperated controls (C-unop) ( $<<0.005$ for each). The DNA SA

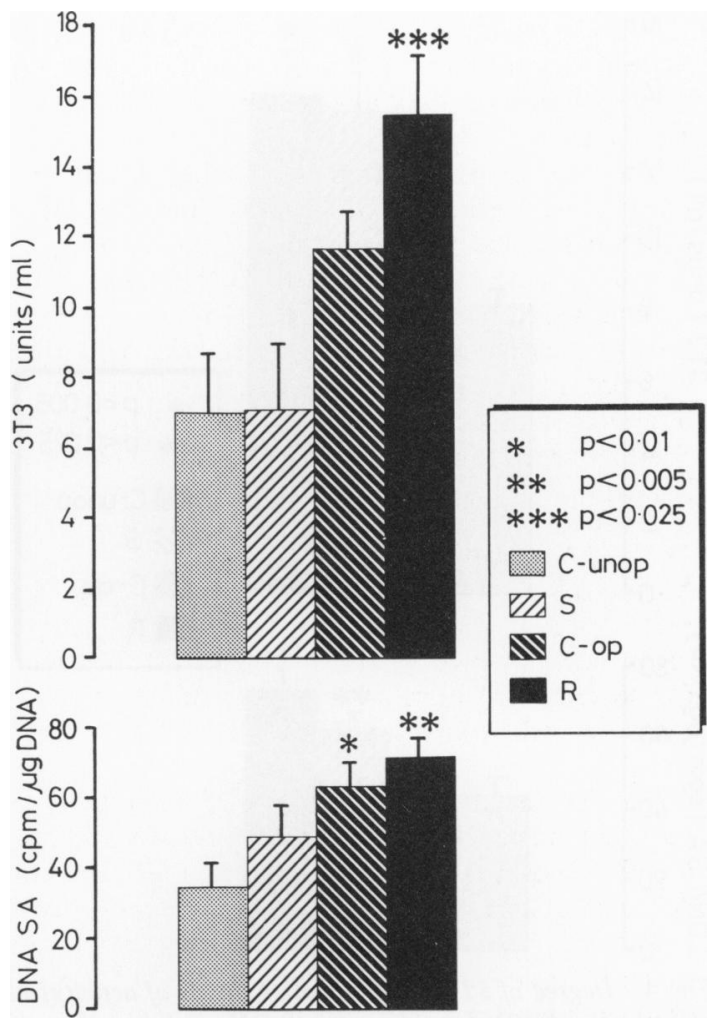

Fig. 3 Degree of $3 T 3$ cell stimulation (units of activity/ml plasma) by platelet free plasma, and DNA SA (cpm/ $\mu \mathrm{g}$ $D N A$ ) for each group at 1 week postoperative. Shown are the means $\pm S E$ and statistics reflect comparison to $C$-unop group using Student's $t$ test.

was also significantly increased for both groups ( $\mathrm{p}<0.025, \mathrm{p}<0.005$ respectively).

\section{CHARACTERISATION OF PLASMA GROWTH} FACTOR

As shown in the Table, growth factor activity was retained after dialysis with membrane pore sizes of

Table Characterisation of growth factors

\begin{tabular}{llc}
\hline Specimen & Treatment & $\begin{array}{l}\text { Residual activity } \\
(\% \pm S E)\end{array}$ \\
\hline Plasma & Dialysis: pore size & \\
& 3500 & $89 \cdot 5 \pm 3 \cdot 1$ \\
& $6000-8000$ & $101 \pm 15 \cdot 5$ \\
& $12000-14000$ & $<1$ \\
& Heat & $50 \cdot 4 \pm 7 \cdot 3$ \\
& DTT & $90 \pm 9 \cdot 4$ \\
\hline
\end{tabular}

Retention of growth factor activity of plasma from $\mathrm{R}$ and C-op groups after dialysis, heating and treatment with DTT utilising the 3T3 growth factor assay. 


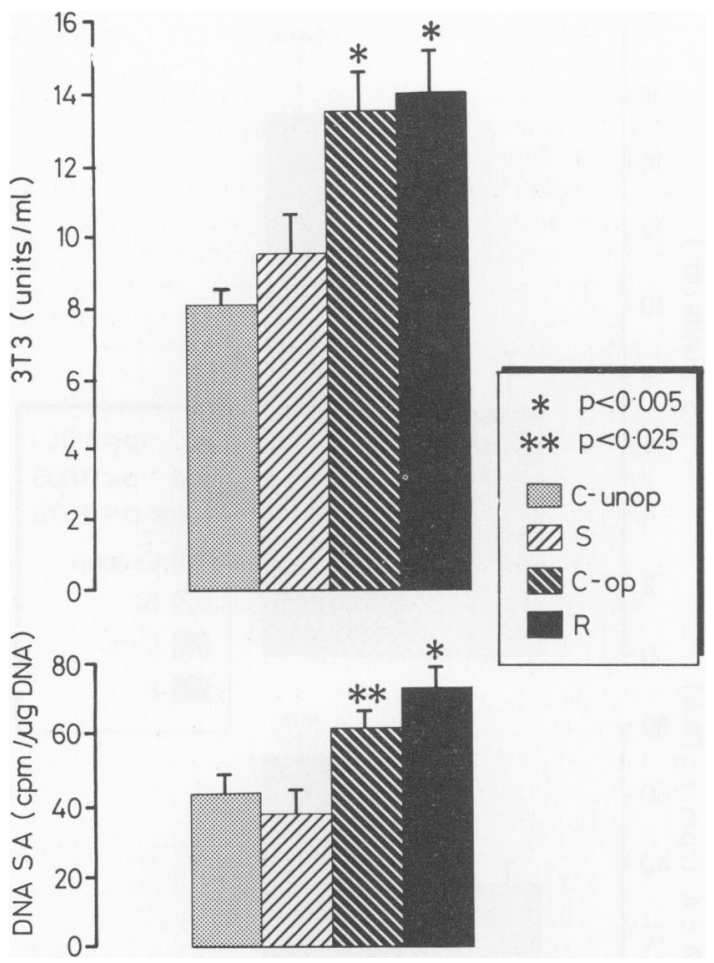

Fig. 4 Degree of $3 T 3$ cell stimulation (units of activity/ml plasma) by platelet free plasma, and DNA SA (cpm/ $\mu \mathrm{g}$ DNA) for each group at 2 weeks postoperative. Shown are the means $\pm S E$ and statistics reflect comparison to $C$-unop group using Student's t test.

$3500 \mathrm{~d}$ as well as $6000-8000 \mathrm{~d}$. Virtually all activity was lost after dialysis with a membrane pore size $12000-14000 \mathrm{~d}$. Heating the sample resulted in a $50 \%$ decrease in activity. Treatment with the reducing agent DTT resulted in retention of $90 \%$ of initial activity.

\section{AUTORADIOGRAPHIC AND HISTOLOGICAL STUDIES}

As shown in Figure 5, villus height and crypt depth was increased only for those animals undergoing resection $(R)(p=0.0006)$. The number of labelled crypt cells was increased for the sham operated group $C$-op $(p=<0.004)$ and for the resected group $R$ $(p=0.0006)$, with the latter $(R)$ significantly greater than C-op $(p=0.0006)$. Likewise, the labelling index was increased for C-op $(p=<0.004)$, and $R$ $(p=0.0006)$ with the latter $(R)$ significantly greater than C-op $(p=0.006)$.

\section{Discussion}

In this study, we have shown the presence of a plasma

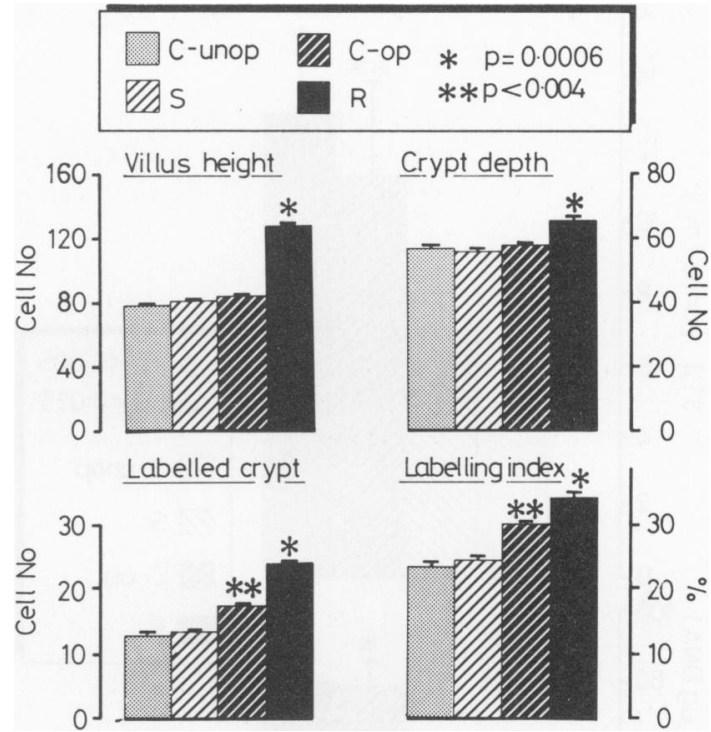

Fig. 5 Morphometric analysis of ileal mucosa including villus height and crypt depth (cell number), number of labelled crypt cells and crypt cell labelling index for rats killed at 2 weeks from each group.

factor(s) that stimulates incorporation of ${ }^{3} \mathrm{H}$ thymidine into a 3T3 fibroblast cell line, concurrent with an increase in DNA synthesis in the remaining ileum after abdominal surgery. Ileal DNA specific activity, crypt cell labelling index, and 3T3 cell stimulation were increased for the operated controls (C-op) and the resected animals (R) as compared with the unoperated controls (C-unop). This effect appears specific for those animals undergoing abdominal surgery because a dorsal incision produced results similar to those of the unoperated control group. The fact that peritoneal incision without intestinal manipulation can stimulate intestinal DNA production at 24 hours, one week, and two weeks postoperative strongly suggests that a humoral growth factor is involved in the adaptation process. While there was stimulation of DNA specific activity and crypt cell labelling index for both the sham operated animals (C-op) and those undergoing resection (R) (Figs 2-4), only the latter group manifested an increase in total DNA in the ileal segment (Fig. 1). Clearly, factors stimulating 3T3 and crypt cell proliferation are not always reflected in an increase in villous height. Consequently, other factors must be involved in this adaptation process.

In summary, the use of the 3T3 growth factor assay now makes it possible to more directly define and characterise the trophic humoral factor(s) involved in intestinal adaptation. Future studies should be 
directed at further isolation of this factor(s) and examination of the mechanism of action.

Extracted from Gastroenterology 1986; 91 with permission, Elsevier Science Publishing Company, New York. Supported in part by Pediatric Gastroenterology Research Training Grant \# AM07471, by the National Institute of Arthritis, Digestive Diseases and Kidney Diseases, Research Grant \# AM32658, and National Cancer Institute Grant \# CA37392. We greatly appreciate the statistical analyses provided by E Allred, the technical assistance of S Smith and the excellent secretarial assistance of $\mathbf{R}$ Sigel.

\section{References}

1 Dowling RH, Booth CC. Structure and functional changes following small intestinal resection in the rat. Clin Sci 1967; 56: 139-49.

2 Nygaard K. Resection of the small intestine in rats. III Morphological changes in the intestinal tract. Acta Chir Scand 1967; 133: 233-48.

3 Hanson WR, Osborne JW, Sharp JG. Compensation by the residual intestine after intestinal resection in the rat. I. Influence of amount of tissue removed. Gastroenterology 1977; 73: 692-700.

4 Weser E, Hernandez MH. Studies of small bowel adaptation after intestinal resection in the rat. Gastroenterology 1971; 60: 69-75.

5 Tilson MD, Wright HK. The effect of resection of the intestine upon the fine structure of the intestinal epithelium. Surg Gynecol Obstet 1971 ; 134: 992-4.

6 Williamson R. Intestinal Adaptation. $N$ Engl J Med 1978; 298: 1393-1402; 1444-50.

7 Feldman FT, Dowling RH, MacNaughton J, et al. Effect of oral versus intravenous nutrition on intestinal adaptation after small bowel resection. Gastroenterology 1976; 70: 712-9.

8 Levine GM, Deren JJ, Yezdmir E. Small bowel resection. Oral intake is the stimulus for hyperplasia. Am J Dig Dis 1976; 21 : 542-6.

9 Levine GM, Deren JJ, Steiger E, et al. Role of oral intake in maintenance of gut mass and disaccharidase activity. Gastroenterology 1974; 67: 975-82.

10 Aharonov A, Pruss R, Herschman H. Epidermal Growth Factors: relationship between receptor regulation and mitogenesis in 3T3 cells. J Biol Chem 1978; 3253: 3970-7.

11 Cooper J, Bowen-Pope D, Raines E, et al. Similar effects of platelet derived growth factor and epidermal growth factor on the phosphorylation of tyrosine in cellular proteins. Cell 1982; 31: 263-73.

12 Gospodarowicz D. Growth factors and their action in vivo and in vitro. Pathology 1983; 141: 201-33.

13 Klagsbrun $M$, Langer $\mathrm{R}$, Levenson $\mathrm{R}$, et al. The stimulation of DNA synthesis and cell division in chondrocytes and $3 \mathrm{~T} 3$ cells by a growth factor isolated from cartilage. Expt Cell Res 1977; 105: 99-108.

14 Ross R, Glomset J, Kariya B, et al. A platelet dependent serum factor that stimulates the proliferation of arterial smooth muscle cells in vitro. Proc Natl Acad Sci USA 1974; 71 : 1207-10.

15 Klagsbrun M. Human milk stimulates DNA synthesis and cellular proliferation in cultured fibroblasts. Proc Natl Acad Sci USA 1978; 75: 5057-61.

16 Scott JF, Fraccastoro AP, Taft EB. Studies in histochemistry: Determination of nucleic acids in microgram amounts of tissue. J Histochem Cytochem 1956; 4: 110.

17 Hinrichs HR, Petersen RO, Baserga R. Incorporation of thymidine into DNA of mouse organs. Arch Pathol 1964; 78: 245-53.

18 Rogers AW. Techniques of autoradiography. New York: Elsevier Publishing Company, 1967. 